\title{
Social Justice Training in Action: A Counseling Psychologist's Role in a Police-Mental Health Collaborative Serving Disadvantaged Youth
}

\author{
James G. Barrett \\ Cambridge Health Alliance/Harvard Medical School
}

\author{
Chad D. Olle \\ Boston College
}

\begin{abstract}
Training programs in counseling psychology have endeavored to integrate social justice into their curricula and prepare their graduates to be agents of change in their communities (Goodman et al., 2004). However, there is too often a disconnect between social justice theory and training and how these principles are actualized in the community (Beer, Spanierman, Greene, \& Todd, 2012). Using a case study of a counseling psychologist's role in developing and administering Safety Net, a police-mental health collaborative to reduce youth contact with the juvenile justice system, this paper provides an example of a counseling psychologist engaged in community collaboration and systems advocacy (Lewis, Arnold, House, \& Toporek, 2002) as integrated parts of his roles as therapist, consultant, and advocate. The authors present the case as an iterative, step-by-step process which can serve as a practical example for professionals and trainees working to translate theory into practice.
\end{abstract}

Keywords: systems advocacy, community collaboration, social justice, juvenile justice, training

Counseling and Psychology scholars have encouraged the field to transcend multicultural competence and endeavor to be agents of change at systemic and structural levels (Ali \& Sichel, 2014; Fouad, Gerstein, \& Toporek, 2006; Goodman et al., 2004; Vera \& Speight, 2003). While various codes and guidelines go to great lengths to emphasize personal reflection and cultural sensitivity, which undoubtedly have had a singular effect on practitioners and their clients, the bridge between individual and systems-level work is still a nebulous notion to many professionals and future professionals. In light of this, there have been renewed calls for trainers to consider non-traditional pedagogies and competencies when training psychologists and counselors (Ali \& Sichel, 2014; Flores et al., 2014; Motulsky, Gere, Saleem, \& Tranthem, 2014). Integrating more social justice education into current curricula will require exposing trainees to practical, real-world examples of systems-level work. The 
purpose of this paper is to add to recent attempts (Ali \& Sichel, 2014; Burnes \& Manese, 2008; LopezBaez \& Paylo, 2009) to address this need while specifically contributing an example of systemic work that takes place removed from the support of a university training program. By outlining a psychologist's role in a community collaborative program, this paper will provide a case study that trainers can use to demonstrate how a counseling psychologist is able to integrate the role of social change agent into their broader identity as a mental health professional.

First, this paper will outline the theory around integrating social justice into practice. Specifically, it will concentrate on community collaboration and systems advocacy (Lewis, Arnold, House, \& Toporek, 2002), activities which seem to bridge individual work and social change. Second, background will be presented on Safety Net, a city-wide collaborative between a counseling psychologist, the local police department, school district, and health services, aimed at reducing juvenile contact with the justice system by linking youth and families with mental health services and supports to promote healthy youth development. The Safety Net Collaborative's implementation has coincided with an almost $60 \%$ decrease in juvenile arrests in Cambridge (Barrett \& Janopaul-Naylor, 2016). Although detailing the psychologist's involvement will be the primary contribution of this paper, the authors will also review literature related to the juvenile justice system and touch on the timeliness of a collaboration between mental health professionals and the police given the bipartisan national conversation concerning reform of the criminal justice system (Giridharadas, 2015). Finally, this paper will detail a psychologist's role in the design and institutionalization of the Safety Net program. In presenting this case, the authors will demonstrate a real world example of a counseling psychologist engaged in meaningful advocacy, specifically through community collaboration and systems advocacy (Lewis et al., 2002).

\section{Social Justice Training and Practice in Counseling and Psychology}

Social justice is the equitable distribution of power, resources, and access to tools of self-determination, and the absence of disproportionate vulnerability to harm. This conceptualization encompasses Prilleltensky's (2012) two-part definition of justice, which includes distributive justice and procedural justice. Distributive justice "refers to the fair and equitable allocation of burdens and privileges, rights and responsibilities, and pains and gains in society" and procedural justice "refers to fair, transparent, informative, respectful, and...participatory decision making processes" (Prilleltensky, 2012, p. 6-7). Psychologists and counselors committed to these ends speak with the understanding that psychological difficulties cannot be conceptualized in a vacuum; they are inextricably bound to the systems of social relations and support from which the individual springs (Prilleltensky, 1999). Thus, as counselors and psychologists concerned for the public good, we have an ethical and moral imperative to leverage our training, privilege, and influence towards justice on behalf of our clients, both preemptively and as a complement to our remedial work.

In their study of doctoral trainees in counseling psychology, Singh et al. (2010) found that trainees integrated social justice into their practice mostly on the micro-level through self-examination and education, aspects of social justice that are more akin to the mandatory ethics of multicultural competence than to community collaboration of systems advocacy. Similarly, trainees at the master's level have indicated a lack of perceived competency and skills with which to apply their emerging awareness of systemic inequities to practices that may help ameliorate those inequities (Collins, Arthur, Brown, \& Kennedy, 2015). Singh et al. (2010) found to a lesser degree that trainees reported social justice integration beyond the self through passing on social justice values as teachers and mentors and through research. Although these are important activities, for many practitioners who are now in the 
field and done with formal training; teaching, mentoring and research are not part of their job description, and they have less opportunity (and available time) to engage in macro-level advocacy (Lewis, 2011).

The good news is that trainees have expressed a commitment to social justice and desire more training in this area (Beer et al., 2012). With curricula already at capacity, however, and internships and jobs demanding experience in traditional counseling settings with traditional counseling skills, trainees, practitioners and faculty struggle to integrate social justice into their practice and curricula respectively. To wit, Miller and Sendrowitz (2011) surveyed current doctoral trainees in counseling psychology, and $58 \%$ of respondents felt that faculty encouraged them to be involved in social advocacy while only $30 \%$ of participants felt that their program allotted enough time, resources, and guidance necessary for engaging in these activities (also see Beer et al., 2012). Similarly, in a review of counseling psychology syllabi, Pieterse, Evans, Risner-Butner, Collins, and Mason (2009) found that although $60 \%$ of instructors included social justice themes in their course objectives (e.g., the nature of various prejudicial "-isms"), very few explicitly focused on roles that counseling psychologists could play in change processes.

\section{Examples of Applied Social Justice}

As contributors to a special issue of The Counseling Psychologist on non-traditional teaching methods, Ali and Sichel (2014) advocated for institutionalizing structural competency as a framework for training counselors and psychologists in social justice and included three examples of training experiences in "anti-oppression" advocacy. Similarly, Goodman et al. (2004) detail a first year experience requirement wherein doctoral students work in urban non-counseling settings to develop skills in prevention, collaboration, and advocacy. While these contributions mark a vital step forward in concretizing social justice practice in counseling psychology and providing a model for training students in collaboration and advocacy skills, the circumstances surrounding these students' involvement differ markedly from those faced by professionals in the field, who are far removed from the flexibility and supports afforded them by a university training program.

Burnes and Manese (2008) present a case study of an American Psychological Association (APA)accredited, pre-doctoral internship program that explicitly integrates social change goals and activities into their training and practice as mental health professionals. Using the six principles of social justice work (Goodman et al., 2004), the authors present examples of how interns have participated in outreach, preventative, and consultative interventions on the community level. For example, interns volunteer for off-site rotations in community settings and lead workshops on cultural stereotypes to raise consciousness.

While social justice is explicitly listed as part of The American Psychological Association's (APA) (2002) Guidelines on Multicultural Education, Training, Research, Practice, and Organizational Change for Psychologists, they shed little light on specifically how counseling psychologists should advocate on the level of systems change, the defining aspect of social justice according to many scholars (Fouad, Gerstein, \& Toporek, 2006; Goodman et al., 2004; Vera \& Speight, 2003). The American Counseling Association (ACA) (2014) has done more to endorse and standardize systems-level considerations by listing the promotion of social justice as a core value and advocacy as a standard in its actual code of ethics (A.7a.). The ACA further developed the advocacy standard in the form of competencies for community collaboration and systems advocacy (Lewis et al., 2002), which provide guidance for how to advocate for clients and students effectively and ethically. Community collaboration has been defined as assuming the role of an ally in the community by being aware of environmental issues that thwart 
healthy growth and development and working with agencies already dedicated to addressing these issues. Systems advocacy takes community collaboration a step further in that advocates take the lead in developing and implementing a plan to systematically identify and eradicate "systemic factors that act as barriers to their students' and clients' development" (Lewis et al., 2002, p. 2).

Perhaps the most concrete example of advocacy is a case study by Lopez-Baez and Paylo (2009) that explores a counselor's involvement in the case of a 13-year old African American boy using Lewis et al.'s (2002) competencies, detailing specific interventions for each competency. Contrasted with Lopez-Baez and Paylo's case study, which concentrates on the case of an individual, this paper will describe a psychologist's role in Safety Net, a community-wide initiative to systematically reduce juvenile contact with the criminal justice system, particularly for minority youth. Instead of using the ACA competencies as an organizational framework, the narrative of this paper prioritizes chronology in order to best highlight the counseling psychologist's progression from solely doing conventional individual work to incorporating community collaboration, and ultimately, systems advocacy activities within the framework of Safety Net. In this way, the paper begins by speaking to many clinicians and trainees where they are and suggests tactics to expand the scope of their practice. It became clear that community collaboration and systems advocacy activities often take place in concert and don't necessarily follow a step-wise progression conducive to this overarching goal. Although the narrative is not organized according to the ACA competencies, the competencies played an important role in guiding what information is included. For reference, the CC and SA activities carried out by the psychologist can be found in Table 1 and Table 2 respectively.

Table 1

ACA Competencies for Community Collaboration

\begin{tabular}{|l|l|}
\hline \multicolumn{1}{|c|}{ ACA Competency } & \multicolumn{1}{c|}{ Example } \\
\hline $\begin{array}{l}\text { 1. Identify environmental factors that impinge } \\
\text { upon students' and clients' development. }\end{array}$ & $\begin{array}{l}\text { No mechanism to ensure effective communication and } \\
\text { collaboration among and between police officers, } \\
\text { psychologists, and other helping professionals. }\end{array}$ \\
\hline $\begin{array}{l}\text { 2. Alert community or school groups with } \\
\text { common concerns related to the issue. }\end{array}$ & $\begin{array}{l}\text { Presented to community on responding to youth } \\
\text { violence and highlighted the importance of } \\
\text { collaboration. }\end{array}$ \\
\hline $\begin{array}{l}\text { 3. Develop alliances with groups working for } \\
\text { change. }\end{array}$ & $\begin{array}{l}\text { Because of visibility in the community, the psychologist } \\
\text { was invited to serve on hiring committees for youth and } \\
\text { family services officers. }\end{array}$ \\
\hline $\begin{array}{l}\text { 4. Use effective listening skills to gain } \\
\text { understanding of the group's goals. }\end{array}$ & $\begin{array}{l}\text { Surveyed and interviewed officers to better understand } \\
\text { their training needs. }\end{array}$ \\
\hline $\begin{array}{l}\text { 5. Identify the strengths and resources that } \\
\text { the group members bring to the process of } \\
\text { systemic change. }\end{array}$ & $\begin{array}{l}\text { Recognized outreach capacity of officers and financial } \\
\text { resources of the city to sustain psychologist's } \\
\text { involvement. }\end{array}$ \\
\hline $\begin{array}{l}\text { 6. Communicate recognition of and respect for } \\
\text { these strengths and resources. }\end{array}$ & $\begin{array}{l}\text { Met with officers individually and as a group to } \\
\text { communicate the central role they would serve in terms } \\
\text { of outreach and follow up with youth and families. }\end{array}$ \\
\hline $\begin{array}{l}\text { 7. Identify and offer the skills that the } \\
\text { counselor can bring to the collaboration. }\end{array}$ & $\begin{array}{l}\text { Offered direct training to officers, on-call consultation, } \\
\text { and direct clinical service to children and families. }\end{array}$ \\
\hline $\begin{array}{l}\text { 8. Assess the effect of counselor's interaction } \\
\text { with the community. }\end{array}$ & $\begin{array}{l}\text { Process evaluation and data collection system is being } \\
\text { constructed. }\end{array}$ \\
\hline
\end{tabular}

Note. ACA Competencies for Community Collaboration adapted from "ACA Advocacy Competencies," by J.A. Lewis, M.S. Arnold, R. House, \& R. L. Toporek, 2002. Retrieved from:

http://www.counseling.org/Resources/Competencies/Advocacy_Competencies.pdf 
Table 2

ACA Competencies for Systems Advocacy

\begin{tabular}{|l|l|}
\hline \multicolumn{1}{|c|}{ ACA Competency } & \multicolumn{1}{c|}{ Example } \\
\hline $\begin{array}{l}\text { 1. Identify environmental factors impinging on } \\
\text { students' or clients' development. }\end{array}$ & $\begin{array}{l}\text { No mechanism to ensure effective communication and } \\
\text { collaboration among and between police officers, } \\
\text { psychologists, and other helping professionals. }\end{array}$ \\
\hline $\begin{array}{l}\text { 2. Provide and interpret data to show the } \\
\text { urgency for change. }\end{array}$ & $\begin{array}{l}\text { Reviewed and shared the results of national reports that } \\
\text { emphasize the necessity of collaboration in systems. }\end{array}$ \\
\hline $\begin{array}{l}\text { 3. In collaboration with other stakeholders, } \\
\text { develop a vision to guide change. }\end{array}$ & $\begin{array}{l}\text { Visited nearby collaborative program with partners in } \\
\text { order to build on best practices and establish working } \\
\text { relationships. }\end{array}$ \\
\hline $\begin{array}{l}\text { 4. Analyze the sources of political power and } \\
\text { social influence within the system. }\end{array}$ & $\begin{array}{l}\text { Petitioned the city to purchase 20 hours of clinical time } \\
\text { from the psychologist. Advocated to police and hospital } \\
\text { leadership to allow time for training. }\end{array}$ \\
\hline $\begin{array}{l}\text { 5. Develop a step-by-step plan for } \\
\text { implementing the change process. }\end{array}$ & $\begin{array}{l}\text { Worked with partners to develop a process map for the } \\
\text { officers to follow as well as a logic model for the } \\
\text { collaborative. }\end{array}$ \\
\hline $\begin{array}{l}\text { 6. Develop a plan for dealing with probable } \\
\text { responses to change. }\end{array}$ & $\begin{array}{l}\text { Developed educational material for parents, families, } \\
\text { and schools to explain the purpose of the collaborative; } \\
\text { made presentations to families and schools to answer } \\
\text { any questions they may have. }\end{array}$ \\
\hline $\begin{array}{l}\text { 8. Assess the effect of counselor's advocacy } \\
\text { efforts on the system and constituents. }\end{array}$ & $\begin{array}{l}\text { Ongoing efforts to be responsive to concerns of families } \\
\text { as well as to revisit policies and procedures to ensure } \\
\text { they are serving the needs of the community. }\end{array}$ \\
\hline
\end{tabular}

Note. ACA Competencies for Systems Advocacy adapted from "ACA Advocacy Competencies," by J.A. Lewis, M.S. Arnold, R. House, \& R. L. Toporek, 2002. Retrieved from: http://www.counseling.org/Resources/Competencies/Advocacy_Competencies.pdf

\section{Advocacy in the Context of Safety Net}

\section{Background Information}

Psychologists who work with significantly disadvantaged youth know all too well that the interventions they use and the recommendations they generate from assessments need to be grounded in the day-today reality of young people if they are to have any impact (Allison, Edmonds, Wilson, Pope, \& Farrell, 2011). Psychologists are frequently confined, however, to the physical context of clinics as well as the services and interventions that fit within billable service codes. Meanwhile, the youth whom they treat are most often in the community, far from the purview of the treating psychologist, who is unlikely to be either present or immediately available when trouble occurs. Along these lines, the first person whom a young person encounters when he or she engages in risky behavior is often a police officer. Despite this seemingly apparent reality, communities tend to implement very little in terms of resources to ensure there is effective communication and collaboration among and between police officers, psychologists, and other helping professionals around the needs and experience of youth who are most at-risk for involvement in the juvenile justice system. Before the establishment of Safety Net, Cambridge was among the cities that did not have systemic structures in place to support this type of collaboration. 
The Safety Net Collaborative was founded in 2008 and includes the Cambridge Police, Health Alliance, Public Schools, and Human Services. The formal mission statement of Safety Net is "to foster positive youth development, promote mental health, support safe school and community environments, and limit youth involvement in the juvenile justice system through coordinated prevention, intervention, and diversion services for Cambridge youth and families" (Cambridge Police Department, 2012). The partner agencies within Safety Net work to identify potentially vulnerable youth and families in the city and coordinate the services and supports available through the respective agencies to best support their strengths and needs. The hub agency is the Cambridge Police Department, which has a Youth and Family Services Unit (known as the YFSU) that consists of six youth resource officers, two juvenile detectives, a sergeant, and a lieutenant devoted solely to youth affairs in the city. This unit affords officers the opportunity to not only respond to crime but to reach out to vulnerable youth and families, collaborate with partners, and act as agents of prevention in the community.

\section{Socioeconomic Factors Impacting Development}

The most basic component of community collaboration and systems advocacy is an awareness of how environmental factors impact healthy growth and development. Mental health professionals bring a unique lens to understanding the complex web of causality underlying behavior. Consistent with training in counseling psychology, Safety Net represents a concerted effort to move away from an understanding of individual behavior in isolation and instead grounds the work and the lives of program participants in a developmental, cultural, and socio-historical context.

Safety Net has been instituted against a historical backdrop of intersecting systemic influences at the local and national levels, particularly increasing economic inequality and the problematic historical relationship between law enforcement officials and communities of color. Cambridge, the home of Safety Net, is home to prestigious academic institutions and state-of-the-art technology and innovation, but like many cities in the country, also suffers from rising income inequality (Bloomberg, 2014). Although the median income in Cambridge is higher than the state average, approximately $46 \%$ of public school children qualify for lunch subsidies (United States Census Bureau, 2014). Further, the rate of poverty has increased by $12 \%$ between 1979 and 2011, with $9.9 \%$ of all families in the city living below the poverty line (City of Cambridge, 2014). While the intersectionality of causality is complicated and not entirely understood, the American Academy of Pediatrics (AAP) posits that poverty is the underlying cause that most contributes to juvenile crime (Braverman \& Murray, 2011).

Others have linked income inequality, as opposed to poverty itself, to crime and specifically violent crime (Hipp, 2007; Kawachi, Kennedy, \& Wilkinson, 1999; Wilkinson, 2004). The link between criminal behavior and income inequality has been explained by relative deprivation, a social psychological phenomenon marked by feelings of anger and resentment due to the perception that one is worse off than one deserves (Smith, Pettigrew, Pippin, \& Bialosiewicz, 2012). Wilkinson (2004) and Marmot (2004) have been especially instrumental in documenting the deleterious social effects of inequality, also referred to as a steep "social gradient" or social hierarchy. Relative social position, or status, has been shown to be a powerful determinant of health because of its relation to agency and social inclusion (Marmot, 2004). Strain theory (Merton, 1968) further helps us understand why disadvantaged individuals, saddled with constraints on self-determination, turn to crime when they are unable to reach culturally-sanctioned monetary goals through culturally-sanctioned channels (as cited by Baron, 2006). In integrating the two theories, Baron (2006) convincingly demonstrates that relative deprivation (e.g., income inequality) is a primary strain associated with delinquent or criminal behavior in youth. 
Unfortunately, addressing all of these macro-systemic inequities is beyond the scope of Safety Net. It is important to acknowledge the tension that exists between helping individuals and families adjust to oppressive systems and challenging those systems that continue to perpetuate material injustice (Prilleltensky \& Stead, 2011). Indeed, one could argue that the juvenile justice system (JJS), as currently constructed, is inherently unjust and needs to be dismantled and built anew with fundamentally different priorities and goals. In the near term, however, involvement with the JJS acts as a powerful risk factor that derails healthy growth and development making it an appropriate target of community collaboration and systems advocacy for counselors and psychologists (Lewis et al., 2002). Safety Net acts as a systemic corrective mechanism that diverts youth from the JJS and provides needed supportsincluding mental healthcare-that may help repair the wounds of generational social and economic disadvantage.

\section{Inequity in the Juvenile Justice System}

Returning to Prilleltensky's (2012) definition of justice, the JJS has become a nexus of distributive and procedural inequity. In the United States, minority youth make up $2 / 3$ of those housed in secure juvenile facilities despite making up only $1 / 3$ of the youth population (Building Blocks for Youth Initiative, 2005; National Center for Juvenile Justice, 2015). More locally, Black youth comprise 38\% of juveniles charged as youthful offenders in the State (Citizens for Juvenile Justice, 2012). Racial disparities have also been documented in the way that the juvenile justice system (JJS) processes youth of color at every decision point (Cabaniss, Frabutt, Kendrick, \& Arbuckle, 2007).

The historical treatment of people of color by police officers is especially troubling. Young Black men in particular have reported more dissatisfaction with and distrust of police than other groups and a disproportionate experience of negative outcomes including being unfairly profiled and "hassled" by police (Brunson \& Miller, 2006). Data from cities across the U.S. show that police officers have racially profiled residents (Amin, 2015; Friedersdorf, 2015; New York Civil Liberties Union, 2015; United States Department of Justice, 2015). Recently, the high profile killings of Michael Brown, Tamir Rice, Eric Gardner, and several other unarmed people of color by police officers in the United States has raised awareness of discriminatory, unlawful, and unnecessarily forceful practices by law enforcement (United States Department of Justice, 2015) and heightened the tension between police and communities of color. The current national conversation puts the importance of psychologists and other helping professionals in collaborating with government officials at all levels to reconstruct a more just and humane criminal justice system into sharp relief.

\section{Mental Healthcare in the Juvenile Justice System}

Part of this reconstruction must include an emphasis on mental health. Systematic discrimination in the JJS begins with minority youth being more likely to have their disruptive behavior interpreted as criminal behavior rather than mental health difficulties or even as developmentally normative (Peck, Leiber, \& Brubaker, 2014). The rate of diagnosable mental health difficulties in the JJS is estimated to be between two and four times the general population with between 40 and $70 \%$ of "offenders" having mental disorders (Coalition for Juvenile Justice, 2000; Myers \& Farrell, 2008). Locally, while data on specific mental health conditions for youth in the system is not recorded, $74.4 \%$ of youth in the state who were on juvenile probation were identified as having a "counseling need" (Citizens for Juvenile Justice, 2012). While contact with the JJS is oftentimes a youth's first access to health care, many analysts have highlighted the lack of screening for mental health difficulty and substance abuse upon entry into the JJS as a major barrier to rehabilitation and needed care (Grisso \& Underwood, 2003). Unfortunately, these same analysts and others have identified the JJS's lack of capacity and infrastructure to carry out said 
activities (Maschi, Hatcher, Schwalbe, \& Rosato, 2008; Myers \& Farrell, 2008). As a result, the prognosis for youth who have contact with the JJS is bleak. Recent estimates of the median placement stay are approximately 65 days with $80 \%$ of youth staying in facilities for at least 30 days and $50 \%$ staying for at least 105 days (US Department of Justice, 2015). Over 50\% of parolees are arrested within a year of release (Myers \& Farrell, 2008). This and other recidivism statistics indict the JJS for not living up to its mission of rehabilitating the youth who transition through the system.

\section{A Counseling Psychologist's Role in the Safety Net Collaborative}

There are varying levels of advocacy to which a counselor or psychologist can be engaged. Although both are forms of advocacy, systems advocacy can be seen as a more involved iteration than community collaboration in that professionals engaged in systems advocacy are not only aware of environmental factors and collaborate with others in order to address them, but take on a leadership role in identifying, planning, and eradicating systemic sources of injustice (Lopez-Baez \& Paylo, 2009). In this case, the counseling psychologist went from doing individual work in a traditional setting to collaborating with community stakeholders to playing an important role in the planning and implementation of a program meant to redress systemic inequities.

\section{Creating Opportunity for Collaboration}

Consistent with the ACA competencies for community collaboration (see Table 1), a psychologist must, "alert community or school groups with common concerns" and "develop alliances with groups working for change." This way, the psychologist casts a wider net for potential advocacy opportunities, and stakeholders know whom to contact for support or assistance. The impetus to start Safety Net occurred during multi-disciplinary interviews to select the officers who were going to comprise the Youth and Family Services Unit (YFSU) of the Cambridge Police Department. The police commissioner reached out to community partners (i.e., schools, after-school programs, community health system) to nominate a representative to take part in the selection process. Because the first author, a counseling psychologist, had given presentations to clinic staff and the community about responding to youth violence, he was "on the radar" as someone with clinical and research background who could contribute expertise to this burgeoning police effort. Consequently, he was well-positioned to be invited to the table when the police were reaching out for partners to help in an effort to better respond to youth in the community.

At these interviews, the counseling psychologist sat next to a school principal, a police lieutenant and the director of the city's afterschool program to interview and select the officers that had the necessary qualities (e.g., patience, a sense of wanting to help young people, a basic understanding of youth development) to be interacting with the city's most disadvantaged youth daily. In particular, the partners recognized that many of the young people, to whom these officers would be first responders, would have mental health concerns. All of the partners at the table realized at the conclusion of the interviews, however, that there was nothing in place to support an ongoing collaboration between officers and service providers to ensure that they could link young people and their families with effective services and supports. It was in response to this need that Safety Net began to emerge, and the psychologist began taking part in activities that align with the ACA's systems advocacy competencies. As the following section details, the psychologist played a central role in providing and interpreting data and implementing a vision and plan for the change process. 


\section{Program Planning}

\section{Researching Best Practices}

Safety Net was developed as an effort to put into practice what is prescribed in the juvenile justice literature. One of the hallmarks of training in counseling psychology is instilling in students the capacity to accurately understand research data and bring its impact on vulnerable populations to bear (Myers, 2007). In forming the basic structure for Safety Net, the partners (i.e., police leadership, psychologist, school and city officials) reviewed the major national reports on mental health and juvenile delinquency in an effort to gain a better understanding of the scope of the issue nationally.

The Safety Net partners discovered that scholars and practitioners have consistently recommended that change is needed at the systems level in order to address the incarceration rates among youth as well as their treatment by JJS officials and have urged police, providers, and policy-makers to collaborate and engage in advocacy (MacKinnon-Lewis, Kaufman, \& Frabutt, 2002; Myers \& Farrell, 2008). MacKinnon et al. (2002) highlight the ineffectual nature of interventions from which youth and families receive fragmented services from multiple providers who do not collaborate. These authors stress the need for an organizing body to coordinate services and communication between agencies as well as a community-wide coalition including law enforcement, healthcare providers, and school personnel. Similarly, the Building Blocks for Youth Initiative (2005), a project by the Center for Children's Law and Policy, released a collection of case studies and vignettes that outline best practices for reducing racial and ethnic disparities of youth involved in the JJS. Within the project, collaboration and systems level advocacy are ubiquitous. The literature has been clear that, as professionals, we cannot work in silos; effective treatment of systemic issues that impact vulnerable youth requires effective communication and collaboration across systems (Burrell, 2004; U.S. Department of Health and Human Services, 2001; Weist \& Cooley-Quille, 2001). To this we would add that collaboration with mental health professionals allows for the training of officers and other JJS officials to be aware of sociohistorical context and how biases influence their decision making-in short, to be more multiculturally competent.

Despite the call in the literature for these types of collaborative efforts, it seems actual programs that live up to this standard are few and far between. From past training experiences, the counseling psychologist was aware that the Police Community Partnership Program of the Yale Child Study Center (Marans, Murphy, Rosenheck, \& Berkowitz, 2005) was a well-established exception in close proximity to Cambridge. As a part of developing a vision for change, the partners in Safety Net visited this program and were able to observe firsthand how New Haven police and mental health providers collaborate to respond to families impacted by violence or other traumatic events. Not only did this site visit afford a tremendous opportunity for learning, it also allowed the partners time to learn about and communicate respect for the strengths and resources that members of the collaborative brought to the change process, which are key ingredients to facilitating effective community collaboration (see Table 1). After the site visit, the Safety Net partners were better situated to develop a vision for how the role of the psychologist could shift so that his services could be more available to the evolving collaborative effort.

\section{Navigating Systemic Barriers and Resistance}

One of the biggest obstacles for psychologists and counselors in collaborating with community partners is the pressure to meet the productivity expectation of billed visits. Hospitals and health care systems rely on psychologists to provide office-based treatment services in order to be reimbursed by third-party payers such as health insurance companies. Therefore, any activities by a psychologist that are outside of a billable visit can result in lost revenue for his or her employer. As a result, most psychologists have 
an expectation that a certain percentage of their time (for the Safety Net psychologist it was $65 \%$ ) be devoted to billable visits. This expectation leaves very little time available for advocacy and prevention activities. Indeed, healthcare organizations can systematically neglect these important activities because they have not been monetized to the degree that traditional treatment has. Thus, in many ways priorities in the healthcare system are often are based on profit more than on public health and well-being (Frank \& Glied, 2007).

According to the systems advocacy competencies, psychologists must be prepared to "analyze sources of political power and social influence within the system" (see Table 2). In order to facilitate the collaboration, the partners of Safety Net had to petition the city of Cambridge to partner with the Cambridge Health Alliance (the psychologist's employer) and the Cambridge Police Department to buy out and hold 20 of the psychologist's clinical hours per month to devote to the Safety Net Collaborative. This plan to cost share was key to ensuring that the collaboration between the police and psychologist could be sustainable. While grant funding can be an excellent mechanism to buy out time for collaborations, problems tend to arise when the grant period ends, and often the collaborations that psychologists have worked hard to develop cease to exist. It was critical that the Safety Net partners viewed the counseling psychologist as a key contributor to this effort and someone whose skills were worthy of the investment of city resources.

In terms of delivering the officers the appropriate training and consultation, the psychologist had to account for the executive leadership at both the police and community-hospital levels. The police leadership would have to agree to make time available during the busy academy training schedule and provide time away from being deployed in the school to receive this training. The hospital leadership would have to agree to grant the counseling psychologist time away from clinical duties for him to provide formal training and consultation. The psychologist appealed to the police leadership that increasing the officers' capacity to identify and respond to youth experiencing a mental health crisis would effectively lead to a reduction in the number of times they are likely to have to respond to future crises. On the hospital side, the partners made a similar appeal to leadership making the case that police officers who were well-trained to collaborate with mental health providers would improve access for youth and families who are most in need of services.

A major form of resistance unique to a police-mental health collaboration involved policies and procedures for information sharing. Psychologists are ethically and legally bound to confidentiality standards making collaborations with non-practitioners potentially delicate. Indeed, the Collaborative for Change - a partnership coordinated by the National Center for Mental Health and Juvenile Justice - is spearheading an effort to provide technical assistance and support for information sharing between law enforcement and mental health to address this very issue (Shufelt, Cocozza, \& Skowyra, 2010). In response to the issue of confidentiality, the legal teams of the police department and Cambridge Health Alliance crafted a release that allowed for a parent or legal guardian to grant permission for the partners in Safety Net to discuss a child or family and whether there were supports we could put in place to help. The release of information did not allow clinicians to disclose HIPAA (Health Insurance Portability and Accountability Act) protected information, but did allow for officers to consult the Safety Net psychologist about the case and have the psychologist reach out to the family if indicated.

\section{Missed Opportunities}

When selecting officers for the YFSU, the partners within the Safety Net Collaborative worked to represent the diversity of the Cambridge community. The majority of the officers are people of color, 
and three out of the eight officers identify as female. It is important to recognize, however, that while efforts were made to ensure that the YFSU accurately represented the community, an opportunity was missed to engage youth and families from the community in a meaningful way to guide the development of the collaborative. This exclusion was not deliberate, but nonetheless a major oversight in the process of trying to formulate a working program that could be of service to the community as quickly as possible. The partners soon realized that by failing to include the voice of families at this critical juncture they would have to intensify their efforts to reach out to families and explain the goals of Safety Net and the potential benefits of having police officers in a helping role. To help remediate this oversight, members of Cambridge's "Kid Council", an advisory board comprised of city youth, was consulted on an ongoing basis to generate feedback on what was working well with Safety Net and what had the potential to improve.

\section{Program Implementation: Psychologist as Trainer, Consultant and Clinician}

After meeting several times and visiting a nearby program to research best practices, the Safety Net partners proposed a plan to both the leadership of the city as well as the hospital for integrating mental health training and services with the work of the officers from the YFSU. The plan was comprised of three components directly involving the counseling psychologist: (a) direct training for officers in juvenile mental health and youth development, (b) direct and available consultation to a psychologist in person at regular meetings and on-call via cell phone or pager and (c) access to mental health care and services for the families with whom they work.

\section{Assessment of Training Needs}

Psychologists are expected to keep up with current research on effective interventions and assessments for disadvantaged youth, the clinical skills to deliver therapeutic care, and an appreciation of environmental influences on behavior, while police officers, as a collective, tend to be action-oriented and are trained to respond to a crisis through gaining and maintaining control. The challenge for the Safety Net partners was to find a way to effectively integrate the counseling psychologist's knowledge and training with the experience of the officers.

In the early days of Safety Net, it was important for the counseling psychologist to acknowledge any preconceptions the officers may have had about psychologists or mental health providers. The police officers admitted that sometimes they see psychologists as out of touch with the realities of what officers encounter "on the streets" with youth. Others reported interactions they had with psychologists or psychiatrists who seemed dismissive of their opinion of what could be helpful for a young person. The psychologist was careful to explain that he did not want to be seen as an expert who is brought in to tell the officers how to do their jobs or to evaluate their performance.

Prior to any type of formal mental health training or consultation being offered to the officers, the psychologist met with and surveyed them as a unit to get a better understanding of their training needs. The Safety Net partners recognized that some officers may not feel comfortable speaking up in meetings and voicing that they did not feel listened to or acknowledged. Consequently, to protect the anonymity of the officers, the partners arranged for the lieutenant of the YFSU to meet regularly with individual officers and then provide feedback to the psychologist on a regular basis in aggregate form.

Taking a strengths-based approach consistent with his training (Goodman et al., 2004), the counseling psychologist recognized that the police have an outreach capacity that is unparalleled. Because of the nature of their professional duties, they are mostly out of the station in the community and can swiftly respond to a crisis. Accordingly, police are often the first responders to incidents involving runaways, 
domestic aggression, and community violence-which by extension means they are often the first responders for youth with mental health needs. The program operates with the understanding that police officers who have extensive training in mental health and who have access to a clinician for consultation are better suited to offer assistance to disadvantaged youth experiencing mental health difficulties.

Officers expressed that they would value a reliable psychologist whom they could call when they encountered mental health concerns. Both the psychologist and police leadership made it clear to the officers that in training them in juvenile mental health and development, they were not expected to take on the role of clinician or social worker. Instead, the goal was to help them recognize indicators associated with mental health difficulties and partner with the psychologist to put appropriate services and supports in place. For this collaboration to work, the police officers had to trust the counseling psychologist as someone who would be there when called upon. This was an organic process and took time to develop; it was not a procedure that could be laid out in a manual and then followed. Thus, it is critical that counselors and psychologists who embark on similar partnerships make sure to dedicate adequate time to building mutual trust and respect in their relationships with partners.

After assessing the needs of the police officers, it became apparent to the psychologist that they had two primary concerns: (a) they did not know how to differentiate between a young person who had a mental health diagnosis and one who did not, and (b) when they had reached out to psychologists and therapists in the past they frequently heard back that the therapist could not speak to them at all due to confidentiality. In other words, in their day-to-day encounters with youth, the officers wanted to better understand how to recognize youth who need mental health services and how to get them help.

\section{Training the Officers}

The police had a brand new unit with six youth resource officers, two detectives, a sergeant, and a lieutenant ready to patrol historically disadvantaged communities with no training in youth development and youth mental health and only a cursory knowledge of resources within the city to which to refer families who needed support. The partners within the Safety Net Collaborative informed the schools in the city that providing the officers training on youth development and youth mental health would be a priority. Further, the counseling psychologist began to work with police leadership on ways to formalize a working collaboration in order to facilitate this training. As a result, the psychologist developed and delivered a series of four trainings, 2 hours in duration each, which were integrated into the YFSU officers' schedule to cover multicultural competencies, addressing disproportionate minority contact with police, juvenile mental health, and healthy adolescent development.

The trainings for the officers focused on the fundamentals of youth development, recognizing and understanding youth mental health, and the principles of connecting and communicating with youth. These trainings occurred over the course of several weeks as part of the YFSU officers' "academy time," which is built-in, protected time for officers to devote to training. In addition to the trainings conducted by the psychologist, Strategies for Youth, an organization devoted to juvenile justice policies, trained the officers in their "Policing the Teen Brain" program (Bostic, Thurau, Potter, \& Drury, 2015). This training focuses on helping police understand how adolescent brain development can be linked to risky behaviors and how police can best respond to youth in crisis. The officers in the YFSU also went through training on reducing disproportionate minority contact in the juvenile justice system, while the entire police department went through trainings on multicultural understanding and reducing implicit bias in policing. 
This paper has concentrated largely on the healthy development of youth, but an emphasis on mental health not only benefits youth at risk of JJS involvement, but also officials that make up the systems that perpetrate injustice. Just as we pay close attention to the social embeddedness of disadvantaged youth, so must we recognize the oppressive micro- and macro-cultures that socialize police officers to harbor implicit and explicit biases against racial minorities and exercise authority through coercive control (Terrill, Paoline, \& Manning, 2003). National trends in police bias and brutality are symptomatic of generational pathology that is endemic in our society and around the world. Psychologists, counselors, and other health professionals who aspire to be multiculturally competent and agents of social justice have a role to play in healing these cultural wounds.

\section{Psychologist as Consultant and Clinician}

While the psychologist's roles in program development and implementation were critical to the establishment of Safety Net, he also provides traditional services to youth and families. As a consultant, the psychologist holds regular meetings with each officer to discuss the youth and families with whom they are working as well as provide guidance as needed on topics ranging from techniques to help engage a withdrawn youth to service referrals for families. The psychologist also serves as a team leader on one of the outpatient evaluation teams of a community hospital in Cambridge. The leadership of the outpatient department agreed to reserve one of his intake slots for evaluation of families referred by Safety Net. This was done in an effort to improve access to mental health services to those families that are most in need and, due to long waiting lists, health insurance restrictions, and other barriers to care, perhaps would not have access to services otherwise. The psychologist also performs psychological assessments on youth referred through Safety Net to ensure a proper bio-psycho-socialcultural formulation as well as culturally-relevant treatment planning. Finally, the psychologist serves as a supervisor for doctoral-level psychology interns and postdocs who provide individual and family psychotherapy for Safety Net youth and families at the Cambridge Health Alliance. Through this training role, the psychologist works to foster a commitment in the next generation of psychologists to serve families in need.

\section{Acknowledgement of Positionality}

Although this paper underscores the importance of advocacy and differentiates it from multicultural competence, the authors do not want to underemphasize the latter or assume multicultural competence for those taking part in advocacy. A key component of multicultural competence is awareness of one's own intersecting social identities, the differential privileges they afford us, and the biases we bring to our work (Sue \& Sue, 2008). Similarly, the first and second authors recognize that any project which aims to make meaning or relay knowledge is embedded in our unique individual and collective contexts. Both authors of this case study are White men, benefiting from intersecting and compounding privileges that materially separate us from the context from which our clients and in this case, the participants in the Safety Net program, emerge. While Safety Net does not address all of the systemic inequities that contribute to our clients' difficulties, it is our firm belief that without at least accurately understanding these systemic factors, a psychologist cannot formulate a culturallycompetent approach that stems from an understanding of the problem and those affected $(T e o, 2015)$. 


\section{Conclusion}

There are a growing number of research-practitioners who argue for social action as an indispensable activity in the repertoire of counseling psychologists (Goodman et al., 2004; Ali \& Sichel, 2014; Buki, 2014). While their efforts have helped rewrite the agenda for training a new generation of counseling psychologists, it seems that practice has not kept pace. Though a considerable amount of the barriers to social action are due to the systems within which counseling psychologists operate, part of the disconnect has been a lack of exposure to professionals engaged in community collaboration and systems advocacy. Without these real-world examples, counseling psychologists may not recognize opportunities for advocacy including those chances to reform the very systems that limit their ability in the first place. This paper has attempted to address this void in the literature by presenting a real-world example of a counseling psychologist engaged in community collaboration and systems advocacy.

Early on in the change-process, the psychologist was recruited due to his visibility in the community, which stemmed from related education and consultation efforts. This is a good example of how opportunities for advocacy can arise as a result of getting to know a community through outreach activities. Once the psychologist had a seat at the table, he called on a unique combination of research and clinical training, all with a focus on context and social justice, to advocate for an agenda wherein the mental health needs of community members was a priority. Further, he needed to advocate for himself as a professional with skills and know-how that were vital to the collaboration's mission. This necessitated an active listening stance in order to best understand what strengths were already represented by collaborative members and how he could assist the team in reaching their agreed-upon goals. Before a plan could be put in place, sources of systemic influence and resistance had to be identified and accounted for. As part of this process, he needed to secure buy in from stakeholders at all levels of the collaborative. Finally, he had to be committed to delivering on the goals set forth by the partners and demonstrate a capacity to be present and attuned to the needs of the partners and stakeholders.

By utilizing the definitions of community collaboration and systems advocacy put forth by the ACA, this paper made the psychologist's involvement concrete, yet hopefully easy to map onto other systemic barriers to healthy development. By following the narrative starting from early in the process, professionals and trainees may gain a better understanding of how a psychologist can transition from traditional one-on-one psychotherapy to incorporating various advocacy roles into their work as counseling psychologists. While this paper makes a contribution to this end, more examples of advocacy are needed in the literature to serve as potential guideposts on how to put training into action.

\section{Next Steps for the Safety Net Collaborative}

Now that Safety Net has been established in the community, the partners are focused on outcome evaluation and partnering with other communities to see if components of the Safety Net model can be replicated. In terms of outcomes, the psychologist is working with stakeholders to track youth and families served by Safety Net to assess its impact on keeping youth in school and out of detention. Particular attention is being paid to possible disproportionate minority contact with police as well as implicit bias on decisions regarding suitability for diversion. For example, all diversion decisions are reviewed by a team that includes the officer and his or her supervisor, the psychologist, and at least one other Safety Net team member to ensure that they are equitable. In working with other communities, the Safety Net stakeholders-in an effort to intentionally address systemic inequities-are stressing the following: (a) training of police officers in youth mental health and implicit bias, (b) establishing 
authentic and sustainable partnerships between police officers and mental health practitioners, and (c) diverting youth from arrest whenever possible with an emphasis on treatment and restorative justice rather than punishment. The hope is that as communities adopt these policies the tide can be slowly turned towards a more fair and equitable juvenile justice system.

\section{Author Contact Information}

Correspondence regarding this article should be directed to: James G. Barrett, Cambridge Health Alliance, Macht Building $3^{\text {rd }}$ Floor 1493 Cambridge St., Cambridge, MA 02139

Email: jbarrett@challiance.org

Dr. James Barrett is the Director of School-Based Programs in the Department of Child and Adolescent Psychiatry at the Cambridge Health Alliance. He is an Instructor of Psychology in the Department of Psychology at the Harvard Medical School and the Clinical Coordinator of the Cambridge Safety Net Collaborative

Chad Olle is pursuing a PhD in Counseling Psychology at Boston College. He has a Master of Science degree in Community Counseling and a Bachelor of Arts degree in English Literature. He identifies as an aspiring critical psychologist and activist and is active in campus movements that fight institutional racism.

\section{References}

Ali, A., \& Sichel, C. E. (2014). Structural competency as a framework for training in counseling psychology. The Counseling Psychologist, 42(7), 901-918.

Allison, K. W., Edmonds, T., Wilson, K., Pope, M., Farrell, A. D. (2011). Connecting youth violence prevention, positive youth development, and community mobilization. American Journal of Community Psychology, 48, 8-20. doi:10.1007/s10464-010-9407-9

American Counseling Association. (2014). 2014 ACA code of ethics: As approved by the ACA Governing Council. Retrieved from: http://www.counseling.org/resources/aca-code-of-ethics.pdf

American Psychological Association. (2002). Guidelines on multicultural education, training, research, practice, and organizational change for psychologists. Retrieved from:

http://www.apa.org/pi/oema/resources/policy/multicultural-guideline.pdf

Amin, S. (2015). A police force confronts its racial bias. Al Jazeera America. Retrieved from: http://america.aljazeera.com/watch/shows/america-tonight/articles/2015/2/23/kalamazoopolice.html

Baron, S. W. (2006). Street youth, strain theory, and crime. Journal of Criminal Justice, 34(2), 209-223.

Barrett, J. G., \& Janopaul-Naylor, E. (2016). Description of a collaborative community approach to impacting juvenile arrests. Psychological Services, 13(2), 133-139. 
Beer, A. M., Spanierman, L. B., Greene, J. C., \& Todd, N. R. (2012). Counseling psychology trainees' perceptions of training and commitments to social justice. Journal of Counseling Psychology, 59, 120-133. doi:10.1037/a0026325

Bloomberg. (2014). Most income inequality: U.S. cities. Retrieved from: http://www.bloomberg.com/visual-data/best-and-worst//most-income-inequality-us-cities

Bostic, J.Q., Thurau, L., Potter, M., \& Drury, S. S. (2015). Policing the teen brain. Journal of the American Academy of Child and Adolescent Psychiatry, 53(2), 127-129.

Braverman, P. K., \& Murray, P. J. (2011). Health care for youth in the juvenile justice system. Pediatrics, 128(6), 1219-1235.

Brunson, R. K., \& Miller, J. (2006). Young black men and urban policing in the United States. British Journal of Criminology, 46(4), 613-640.

Building Blocks for Youth Initiative. (2005). No turning back: Promising approaches to reducing racial and ethnic disparities affecting youth of color in the justice system. Washington, DC: Center for Children's Law and Policy. Retrieved from: http://cclp.org/documents/BBY/ntb_fullreport.pdf

Buki, L. P. (2014). The relevance of counseling psychology in addressing major social issues. The Counseling Psychologist, 42(1), 6-12.

Burnes, T. R., \& Manese, J. E. (2008). Social justice in an accredited internship in professional psychology: Answering the call. Training and Education in Professional Psychology, 2(3), 176-181. doi:10.1037/1931-3918.2.3.176

Burrell, J. (2004). System of care findings on children with serious emotional disturbance involved with the juvenile justice system. San Francisco: ORC Macro.

Cabaniss, E. R., Frabutt, J. M., Kendrick, M. H., \& Arbuckle, M. B. (2007). Reducing disproportionate minority contact in the juvenile justice system: Promising practices. Aggression and Violent Behavior, 12(4), 393-401. doi:10.1016/j.avb.2006.09.004

Citizens for Juvenile Justice. (2012). Data points. Who does the Massachusetts juvenile justice system serve? Boston, MA: Citizens for Juvenile Justice. Retrieved from : www.cfjj.org

City of Cambridge. (2014). Population and census data. Cambridge, MA. Retrieved from: http://www.cambridgema.gov/CDD/factsandmaps/populationdata

Cambridge Police Department. (2012). Safety Net Collaborative. Retrieved from http://www.centralcity.gov/cpd/communityresources/safetynetcollaborative.aspx

Coalition for Juvenile Justice. (2000). Handle with care: Serving the mental health needs of young offenders. Washington, DC: Coalition for Juvenile Justice. Retrieved from: https://www.ncjrs.gov/pdffiles1/Digitization/194916NCJRS.pdf 
Collins, S., Arthur, N., Brown, C., \& Kennedy, B. (2015). Student perspectives: Graduate education facilitation of multicultural counseling and social justice competency. Training and Education in Professional Psychology, 9(2), 153-160.

Flores, M. P., De La Rue, L., Neville, H. A., Santiago, S., ben Rakemayahu, K., Garite, R., \& Ginsburg, R. (2014). Developing social justice competencies: A consultation training approach. The Counseling Psychologist, 42(7), 998-1020.

Fouad, N. A., Gerstein, L. H., \& Toporek, R. L. (2006). Social justice and counseling psychology in context. In R. L. Toporek, L. Gerstein, N.A. Foud, G. Roysircar, \& T. Israel (Eds.). Handbook for social justice in counseling psychology: Leadership, vision, and action, 1-16.

Frank, R. G. \& Glide, S. A. (2007). Mental health in the main stream of healthcare. Health Affairs, 26(6), 1539-1541.

Friedersdorf, C. (2015). The brutality of police culture in Baltimore. The Atlantic. Retrieved from: http://www.theatlantic.com/politics/archive/2015/04/the-brutality-of-police-culture-inbaltimore/391158/

Giridharadas, A. (2015). Momentum on criminal justice repair. The New York Times. Retrieved from: http://www.nytimes.com/2015/06/23/us/momentum-on-criminal-justice-repair.html?_r=0

Goodman, L. A., Liang, B., Helms, J. E., Latta, R. E., Sparks, E., \& Weintraub, S. R. (2004). Training counseling psychologists as social justice agents: Feminist and multicultural principles in action. The Counseling Psychologist, 32(6), 793-837.

Grisso, T., \& Underwood, L. (2003). Screening and assessing mental health and substance use disorders among youth in the juvenile justice system. Delmar, NY: National Center for Mental Health and Juvenile Justice. Retrieved from: www.ncmhjj.com

Hipp, J. R. (2007). Income inequality, race, and place: Does the distribution of race and class within neighborhoods affect crime rates? Criminology, 45(3), 665-697.

Kawachi, I., Kennedy, B. P., \& Wilkinson, R. G. (1999). Crime: Social disorganization and relative deprivation. Social Science \& Medicine, 48(6), 719-731.

Lewis, J. A. (2011). Operationalizing social justice counseling: Paradigm to practice. Journal of Humanistic Counseling, 50(2), 183-191.

Lewis, J. A., Arnold, M. S., House, R., \& Toporek, R. L. (2002). ACA Advocacy Competencies. Retrieved from: http://www.counseling.org/Resources/Competencies/Advocacy_Competencies.pdf

Lopez-Baez, S., \& Paylo, M. J. (2009). Social justice advocacy: Community collaboration and systems advocacy. Journal of Counseling \& Development, 87(3), 276-283.

Mackinnon-Lewis, C., Kaufman, M. C., \& Frabutt, J. (2002). Juvenile justice and mental health: Youth and families in the middle. Aggression and Violent Behavior, 7(4), 353-363. 
Marans, S., Murphy, R.A., Rosenheck, R.A., \& Berkowitz, S. (2005) Clinical response modality and timing in a police-mental health program for children exposed to violence. Psychiatric Quarterly, 76, 107-121.

Marmot, M. (2004). Status syndrome. Significance, 1(4), 150-154.

Maschi, T., Hatcher, S. S., Schwalbe, C. S., \& Rosato, N. S. (2008). Mapping the social service pathways of youth to and through the juvenile justice system: A comprehensive review. Children and Youth Services Review, 30(12), 1376-1385. doi:10.1016/j.childyouth.2008.04.006

Merton, R. K. (1968). Social theory and social structure. New York: Free Press.

Miller, M. J., \& Sendrowitz, K. (2011). Counseling psychology trainees' social justice interest and commitment. Journal of Counseling Psychology, (2), 159-169. doi:10.1037/a0022663

Motulsky, S. L., Gere, S. H., Saleem, R., \& Trantham, S. M. (2014). Teaching social justice in counseling psychology. The Counseling Psychologist, 42(7), 1058-1083.

Myers, D. (2007). Implication of the scientist-practitioner model in counseling psychology training and practice. American Behavioral Scientist, 50(6), 789-796.

Myers, D. M., \& Farrell, A. F. (2008). Reclaiming lost opportunities: Applying public health models in juvenile justice. Children and Youth Services Review, 30(10), 1159-1177. doi:10.1016/j.childyouth.2008.03.002

National Center for Juvenile Justice. (2015). National disproportionate minority contact databook. Retrieved from: http://www.ojjdp.gov/ojstatbb/dmcdb/

New York Civil Liberties Union. (2015). Stop-and-frisk data. Retrieved from: http://www.nyclu.org/content/stop-and-frisk-data

Peck, J. H., Leiber, M. J., \& Brubaker, S. J. (2014). Gender, race, and juvenile court outcomes: An examination of status offenders. Youth Violence and Juvenile Justice, 12(3), 250-267.

Pieterse, A. L., Evans, S. A., Risner-Butner, A., Collins, N. M., \& Mason, L. B. (2009). Multicultural competence and social justice training in counseling psychology and counselor education $A$ review and analysis of a sample of multicultural course syllabi. Counseling Psychologist, 37(1), 93-115. doi:10.1177/0011000008319986

Prilleltensky, I. (1999). Critical psychology foundations for the promotion of mental health. Annual review of critical psychology, 1(1), 100-118.

Prilleltensky, I. (2012). Wellness as fairness. American journal of community psychology, 49(1-2), 1-21.

Prilleltensky, I., \& Stead, G. B. (2011). Critical psychology and career development: Unpacking the adjust-challenge dilemma. Journal of Career Development, 39(4), 321-340. 
Shufelt, J., Cocozza, J., \& Skowyra, K. (2010). Successfully collaborating with the juvenile justice system: Benefits, challenges, and key strategies. Washington, DC: Technical Assistance Partnership for Child and Family Mental Health.

Singh, A. A., Hofsess, C. D., Boyer, E. M., Kwong, A., Lau, A. S. M., McLain, M., \& Haggins, K. L. (2010). Social justice and counseling psychology: Listening to the voices of doctoral trainees. Journal of Counseling Psychology, 58(2), 159-169. doi:10.1177/0011000010362559

Smith, H. J., Pettigrew, T. F., Pippin, G. M., \& Bialosiewicz, S. (2012). Relative deprivation a theoretical and meta-analytic review. Personality and Social Psychology Review, 16(3), 203-232.

Sue, D. W., \& Sue, D. (2008). Counseling the culturally diverse: Theory and practice ( $5^{\text {th }}$ edition). Hoboken, NJ: John Wiley \& Sons.

Teo, T. (2015). Critical psychology: A geography of intellectual engagement and resistance. The American Psychologist, 70(3), 243-254.

Terrill, W., Paoline, E. A., \& Manning, P. K. (2003). Police culture and coercion. Criminology, 41(4), 10031034.

United States Census Bureau. (2014). Cambridge QuickFacts. Retrieved from: http://quickfacts.census.gov/qfd/states/25000.html

U.S. Department of Health and Human Services. (2001). Youth violence: A report of the Surgeon General (No. NNBCWW). Rockville, MD: Author.

United States Department of Justice. (2015). Juvenile offenders and victims: National report series. Laurel, MD: Office of Juvenile Justice and Delinquency Prevention. Retrieved from: http://www.ojjdp.gov/ojstatbb/publications/statbb.asp?ID=T35

United States Department of Justice. (2015). Investigation of the Ferguson Police Department. Retrieved from: http://www.justice.gov/sites/default/files/opa/pressreleases/attachments/2015/03/04/ferguson_police_department_report.pdf

Vera, E. M., \& Speight, S. L. (2003). Multicultural competence, social justice, and counseling psychology: Expanding our roles. The Counseling Psychologist, 31(3), 253-272.

Weist, M. \& Cooley-Quille, M. (2001). Advancing efforts to address youth violence involvement. Journal of Clinical Child Psychology, 30(1), 147-151.

Wilkinson, R. (2004). Why is violence more common where inequality is greater? Annals of the New York Academy of Sciences, 1036(1), 1-12. 